\title{
Effects of water management on arsenic and cadmium speciation and accumulation in an upland rice cultivar
}

\author{
Pengjie $\mathrm{Hu}^{1}$, Younan Ouyang ${ }^{2}$, Longhua $\mathrm{Wu}^{1, *}$, Libo Shen ${ }^{1}$, Yongming Luo ${ }^{3}$, Peter Christie ${ }^{1}$ \\ 1. Key Laboratory of Soil Environment and Pollution Remediation, Institute of Soil Science, Chinese Academy of Sciences, Nanjing 210008, China \\ E-mail: pjhu@issas.ac.cn \\ 2. Chinese National Rice Research Institute, Hangzhou 310006, China \\ 3. Yantai Institute of Coastal Zone Research, Chinese Academy of Sciences, Yantai 264003, China
}

\section{A R T I C L E I N F O}

\section{Article history:}

Received 15 February 2014

Revised 21 May 2014

Accepted 27 May 2014

Available online 24 November 2014

\section{Keywords:}

Arsenic

Cadmium

Dimethylarsinic acid (DMA)

Rice

Speciation

Water management

\begin{abstract}
A B S T R A C T
Pot and field experiments were conducted to investigate the effects of water regimes on the speciation and accumulation of arsenic (As) and cadmium (Cd) in Brazilian upland rice growing in soils polluted with both $\mathrm{As}$ and $\mathrm{Cd}$. In the pot experiment constant and intermittent flooding treatments gave 3-16 times higher As concentrations in soil solution than did aerobic conditions but $\mathrm{Cd}$ showed the opposite trend. Compared to arsenate, there were more marked changes in the arsenite concentrations in the soil solution as water management shifted, and therefore arsenite concentrations dominated the As speciation and bioavailability in the soil. In the field experiment As concentrations in the rice grains increased from 0.14 to $0.21 \mathrm{mg} / \mathrm{kg}$ while Cd concentrations decreased from 0.21 to $0.02 \mathrm{mg} / \mathrm{kg}$ with increasing irrigation ranging from aerobic to constantly flooding conditions. Among the various water regimes the conventional irrigation treatment produced the highest rice grain yield of 6.29 tons/ha. The As speciation analysis reveals that the accumulation of dimethylarsinic acid (from $11.3 \%$ to $61.7 \%$ ) made a greater contribution to the increase in total As in brown rice in the intermittent and constant flooding treatments compared to the intermittent-aerobic treatment. Thus, water management exerted opposite effects on Cd and As speciation and bioavailability in the soil and consequently on their accumulation in the upland rice. Special care is required when irrigation regime methods are employed to mitigate the accumulation of metal(loid)s in the grain of rice grown in soils polluted with both As and $\mathrm{Cd}$.
\end{abstract}

C 2014 The Research Center for Eco-Environmental Sciences, Chinese Academy of Sciences. Published by Elsevier B.V.

\section{Introduction}

Arsenic (As) and cadmium (Cd) are two common pollutants found in soil and water. As, especially inorganic As, is classified as a non-threshold carcinogen with a linear dose-response for chronic low level exposure. Cd is a highly toxic heavy metal which can readily accumulate in crops and thus lead to chronic toxicity diseases in livestock and humans. Contamination of agricultural soils by $\mathrm{Cd}$ and As has become an important issue as a result of industrial activities in the proximity of agricultural areas, excessive application of contaminated fertilizers, manures and sewage sludges, and irrigation with water contaminated with metal(loid)s (Roberts et al., 2007; Chen et al., 2008; Williams et al., 2009; Arao et al., 2010). Rice, the most important staple food in Asia, is considered to be a major source of $\mathrm{Cd}$ and As in the human diet in some parts of Japan, India and China (Tsukahara et al., 2003;

\footnotetext{
* Corresponding author. E-mail: lhwu@issas.ac.cn (Longhua Wu).
} 
Mondal and Polya, 2008; Liang et al., 2010). There is therefore an urgent need to develop mitigation measures to reduce As and Cd concentrations in rice.

Several methods have been developed during the past few decades. Selection and breeding of rice cultivars with low As and Cd accumulation have been practiced to reduce As and Cd in the rice grains (Zhang and Duan, 2008; Li et al., 2012; Ye et al., 2012). Water management is another promising method that affects $\mathrm{Cd}$ and As bioavailability in soils and their subsequent uptake by rice (Arao et al., 2009; Rahaman et al., 2011; Hu et al., 2013b). When a paddy field is flooded and the soil has a low redox potential, any Cd present in the soil combines with sulfur (S) to form CdS which has low solubility in water (Bingham et al., 1976). Thus, flooding during the growing season, especially during later stages of plant growth, can effectively reduce $\mathrm{Cd}$ concentrations in rice grains (Arao et al., 2009; $\mathrm{Hu}$ et al., 2013a). In contrast, anaerobic conditions in paddy soils usually lead to the reduction of arsenate (As(V)) to arsenite (As(III)) which enhances the bioavailability of As to the rice plants (Masscheleyn et al., 1991; Marin et al., 1993; Takahashi et al., 2004). Thus, growing rice aerobically results in a marked decline in As accumulation in the rice (Xu et al., 2008; Li et al., 2009b; Hua et al., 2011; Somenahally et al., 2011; Spanu et al., 2012). However, Cd and As often occur together as contaminants in agricultural soils (Liu et al., 2005) and it is therefore necessary to investigate the feasibility of simultaneously mitigating both $\mathrm{As}$ and $\mathrm{Cd}$ accumulation in rice grains through appropriate water management.

The chemical speciation of As influences its biotoxicity. Inorganic As is generally considered to be more toxic than methylated As compounds (Cheng et al., 2004). A large variation in the proportions of inorganic As (As(III) and $\mathrm{As}(\mathrm{V}))$ and organic As (dimethylarsinic acid, DMA) in rice grain has been found but the factors involved are poorly known although both genetic and environmental factors are implicated (Williams et al., 2005; Zavala et al., 2008; Meharg et al., 2009). Water management has been reported to affect As species in rice grains. Compared with flooding, aerobic treatments markedly decreased organic As (mainly DMA) and thus increased the percentage of inorganic As in grain, although the concentrations of inorganic As remained lower than those in flooded rice (Xu et al., 2008; Li et al., 2009b).

Water shortage threatens the sustainability of agricultural systems and food security in many parts of Asia. Rice cultivation consumes more than half of the irrigation water used (Dawe, 2005). Unfortunately, the efficiency of water usage in this sector is very poor and never exceeds $45 \%$ (Hamdy et al., 2003). To meet this challenge many upland rice cultivars have been developed. Brazilian upland rice (Oryza sativa cv. IAPAQ-9), an important upland rice cultivar, was introduced to China during the 1990s and currently thousands of hectares of this variety are cultivated in the central and northern regions to combine water saving with high grain yields (Cheng et al., 2000). To the best of our knowledge all previous reports on the effects of water management practices or experiments on $\mathrm{Cd}$ and/or As accumulation have involved lowland rice cultivars (Arao et al., 2009; Li et al., 2009b; Hua et al., 2011; Somenahally et al., 2011) with few studies on upland rice cultivars. In the present study pot and field experiments were therefore conducted to investigate the effects of water management regimes on both As and Cd speciation and bioavailability in the soil and their accumulation in the grains of Brazilian upland rice.

\section{Materials and methods}

\subsection{Pot experiment}

Soil in the pot experiment was collected from the plow layer $(0-20 \mathrm{~cm})$ of arable land in the suburbs of Hangzhou City, Zhejiang Province, east China. The soil was heavily polluted by decades of deposition of smelter dust. The soil had a pH of 6.95 and contained $35.7 \mathrm{~g} / \mathrm{kg}$ of organic carbon, $3.00 \mathrm{~g} / \mathrm{kg}$ of total N, $0.23 \mathrm{~g} / \mathrm{kg}$ of total $\mathrm{P}$ and $22.8 \mathrm{~g} / \mathrm{kg}$ of total $\mathrm{K}$. Soil total As and Cd were 7.31 and $2.07 \mathrm{mg} / \mathrm{kg}$, respectively. The soil was air-dried and passed through 2-mm nylon sieve. To simulate combined contamination with As, $15 \mathrm{mg} / \mathrm{kg}$ of $\mathrm{As}(\mathrm{V})$ (as $\mathrm{Na}_{2} \mathrm{HAsO}_{4}$ ) in aqueous solution was mixed into the soil. Then the soil was adjusted by weight to $40 \%$ water holding capacity (WHC). After a preincubation conditioning for two weeks the soil was mixed again and placed in plastic pots each containing $1.5 \mathrm{~kg}$ soil. Urea, monopotassium phosphate and potassium chloride were added as basal fertilizers giving $\mathrm{N}, \mathrm{P}$ and $\mathrm{K}$ application rates of $0.36,0.18$ and $0.27 \mathrm{~g} / \mathrm{kg}$. Additional urea was applied as topdressing at a rate of $0.12 \mathrm{~g} / \mathrm{kg} \mathrm{N}$ to all treatments at the tillering stage. Watering tubes and soil moisture samplers (Rhizon SMS, Rhizosphere Research Products, Wageningen, the Netherlands) were installed in the soil in each pot. Brazilian upland rice (Oryza sativa cV. IAPAQ-9) seedlings were transplanted on 15 June 2009 and the water treatments started two days later. There were four water treatments: (1) aerobic, in which the soil was maintained at $70 \%$ WHC throughout the growth period; (2) flooding, in which a $2 \mathrm{~cm}$ layer of water was maintained on the soil surface throughout the growth period; (3) intermittent irrigation, in which the soil was flooded with a $2 \mathrm{~cm}$ layer of water and then the water layer was allowed to decrease gradually through evaporation and plant uptake; when the soil was dry and similar to the 'aerobic' treatment it was flooded again; and (4) intermittent-aerobic, in which the intermittent irrigation was used until the heading stage (26 August) and then changed to aerobic treatment. There were four replicate pots for each treatment. About $10 \mathrm{~mL}$ of soil solution was extracted from each pot through a moisture sampler using a disposable plastic syringe on day 11 (early growth stage), day 49 (tillering stage) and day 101 (maturity stage) after the water treatments. To obtain enough solution in the aerobic treatment the water content of the soil was increased to $75 \%$ of WHC one night in advance of sampling. Plants were harvested on 22 September. The soil in all water treatments was drained off two days before harvest. Soil acetate-extractable metal concentrations were determined after harvest.

\subsection{Field experiment}

The field experiment was conducted in 2010 in the suburbs of Hangzhou City, Zhejiang Province, east China. The soil had a $\mathrm{pH}$ of 5.30 and contained $16.9 \mathrm{~g} / \mathrm{kg}$ organic carbon, $1.46 \mathrm{~g} / \mathrm{kg}$ of total N, $0.68 \mathrm{~g} / \mathrm{kg}$ of total $\mathrm{P}$ and $10.2 \mathrm{~g} / \mathrm{kg}$ of total $\mathrm{K}$. Soil total As and Cd were 6.49 and $0.48 \mathrm{mg} / \mathrm{kg}$, respectively. The soil was slightly polluted by $\mathrm{Cd}$ according to the Chinese Soil Environmental Standard (GB 1995-15618). Brazilian upland rice (IAPAQ-9) seeds were sown on 28 May and the seedlings were transplanted $(25 \mathrm{~cm} \times 25 \mathrm{~cm})$ on 21 June. The basal nutrients were applied one day before transplanting at a dosage of $375 \mathrm{~kg} /$ ha of mixed fertilizer $\left(\mathrm{N}: \mathrm{P}_{2} \mathrm{O}_{5}: \mathrm{K}_{2} \mathrm{O}\right.$ weight ratio of $15 \%: 15 \%: 15 \%)$. The first topdressing was applied on 1 July (10 days after transplanting) at a dosage of $120 \mathrm{~kg} / \mathrm{ha}$ of urea. The second topdressing was applied on 7 July at a dosage of $150 \mathrm{~kg} / \mathrm{h}$ a of urea, $150 \mathrm{~kg} / \mathrm{ha}$ of mixed fertilizer and 
$120 \mathrm{~kg} / \mathrm{ha}$ of $\mathrm{KCl}$. A 1-2 cm water layer was maintained on the soil surface during the first week after transplanting and then the water treatments were applied. There were four watering management treatments: (1) aerobic, where the water was discharged to leave a water layer $\sim 5 \mathrm{~cm}$ deep in the narrow ditch around the plot (about $10 \mathrm{~cm}$ lower than the rice field) to maintain aerobic conditions in the plot; (2) intermittent, where the plot was flooded with water about $3 \mathrm{~cm}$ deep then the water layer decreased gradually through evaporation and leaching; when the soil was dry and similar to the 'aerobic' treatment it was flooded again; the duration of each drying and wetting cycle was about 7 days at the early growth stages and about 5 days from full tillering stage (16 August) to harvest; (3) conventional irrigation, where the plot was irrigated following local conventional irrigation methods to maintain flooded conditions until full tillering stage (16 August) followed by intermittent irrigation; (4) flooding, where the plot was flooded during the entire rice growing season. The total volume of water consumed during the whole growing season was 300, 3702, 6203 and $8704 \mathrm{~m}^{3} / \mathrm{ha}$, respectively, in the four treatments. Total precipitation over the whole crop growing season was $474.3 \mathrm{~mm}$ and was equivalent to $4743 \mathrm{~m}^{3} /$ ha. There were three replicate plots of each treatment fully randomized and the area of each plot was $24 \mathrm{~m}^{2}$ with a 1-m-wide "guard row". Soil $\mathrm{HCl}$ extractable metal concentrations were determined immediately after harvest on 16 October.

\subsection{Measurements}

Soil properties were determined following the methods of Sparks et al. (1996). Soil total metals were determined by digestion of $0.25 \mathrm{~g}$ samples with $12 \mathrm{~mL} \mathrm{HCl}-\mathrm{HNO}_{3}$ (4:1, V/V). Soil total As was determined by digestion of $0.25 \mathrm{~g}$ samples with $12 \mathrm{~mL} \mathrm{HNO}_{3}-\mathrm{H}_{2} \mathrm{SO}_{4}$ (5:1, V/V). Soil available metal(loid)s in the pot (neutral) and field (acid) experiments were extracted with $1 \mathrm{~mol} / \mathrm{L} \mathrm{HAc}$ and $0.1 \mathrm{~mol} / \mathrm{L} \mathrm{HCl}$, respectively (Sparks et al., 1996). The fresh soil water contents were determined simultaneously.

After harvest, shoot samples (straw, husk, brown rice) in both experiments were washed with deionized water and dried at $50{ }^{\circ} \mathrm{C}$. Plant Cd was determined by digestion of $0.5 \mathrm{~g}$ ground samples with a mixture of $6 \mathrm{~mL} \mathrm{HNO}_{3}$ and $4 \mathrm{~mL}$ $\mathrm{HClO}_{4}$. The total As in shoot samples was determined by digestion of a $0.2-0.3 \mathrm{~g}$ ground sample with $6 \mathrm{~mL} \mathrm{HNO}_{3}$ and $2 \mathrm{~mL} \mathrm{H}_{2} \mathrm{O}_{2}$. Certified reference materials GBW07401 and GBW07603 (Institute of Geophysical and Geochemical Exploration, Langfang, Hebei Province, China) were used for quality control.

Cadmium in soil solution samples and digest solutions was determined by flame atomic absorption spectrophotometry (Varian SpectrAA 220FS, Varian, Palo Alto, USA) or by graphite furnace atomic absorption spectrophotometry (Varian SpectrAA 220Z, Varian, Palo Alto, USA). Arsenic in the soil solution and digest samples was determined by atomic fluorescence spectrometry (AFS-930, Beijing Jitian Instruments, Beijing, China).

Arsenic speciation in the brown rice (inorganic As(III) and $\mathrm{As}(\mathrm{V})$ and organic DMA) was determined by HPLC-ICP-MS (7500a, Agilent Technologies, Palo Alto, USA) following an extraction of the rice flour with $2 \mathrm{~mol} / \mathrm{L}$ trifluoroacetic acid (TFA) according to the method developed by Williams et al. (2005).

\subsection{Statistical analysis}

Statistical analysis was performed using the SPSS version 16.0 for Windows software package (SPSS Inc., Chicago, USA). Means were compared by one-way analysis of variance and Duncan's multiple range test at the 5\% level. Data are presented as mean values \pm standard error (SE) of 4 and 3 replicates in the pot and field experiments, respectively.

\section{Results}

\subsection{As and Cd dynamics in the pot experiment}

As and Cd concentrations and As speciation in the soil solution were markedly affected by the different water regimes (Table 1). During the growing season the As(III) concentration in the soil solution always followed the order flooding > intermittent $>$ intermittent-aerobic $>$ aerobic. The flooding treatment resulted in tens or even hundreds of times higher concentration of As(III) in the soil solution than the other water treatments and especially the aerobic treatment. In the intermittent-aerobic treatment the As(III) concentration in the soil solution decreased greatly on day 101 when irrigation regimes shifted from intermittent to aerobic. In contrast to $\mathrm{As}(\mathrm{III})$, the concentrations of $\mathrm{As}(\mathrm{V})$ in the soil solution in the aerobic treatment were higher than those in the other treatments. As(III) was the dominant form of As in the soil solution in the flooding and intermittent treatments as well as the intermittent stage of the intermittent-aerobic treatment and accounted for $68 \%-99 \%$ of the total As. As(V) dominated in the aerobic treatment and the aerobic stage of the intermittent-aerobic treatment. Total As concentrations (the sum of $\mathrm{As}(\mathrm{III})$ and $\mathrm{As}(\mathrm{V})$ ) in the soil solution in the aerobic treatment were 3-16 times lower than those in the other treatments. On the other hand the aerobic treatment gave higher Cd concentrations in the soil solution on day 49 and day 101 but the flooding treatment gave lower Cd concentrations during the growing season.

\subsection{Post-harvest soil extractable As and $\mathrm{Cd}$ in the pot and field experiments}

Because of the different soil $\mathrm{pH}$ status, soil available metal (loid)s after harvest in the pot (neutral) and field (acid) experiments were extracted with $1 \mathrm{~mol} / \mathrm{L} \mathrm{HAc}$ and $0.1 \mathrm{~mol} / \mathrm{L}$ $\mathrm{HCl}$, respectively (Table 2). In the pot experiment soil acetate-extractable As in the flooding treatment was $5.72 \mathrm{mg} / \mathrm{kg}$, significantly higher than those in the other treatments. Soil acetate-extractable Cd ranged from 1.04 to $1.89 \mathrm{mg} / \mathrm{kg}$ and showed no significant difference among the various water treatments. In the field experiment soil available As and Cd were 0.03-0.07 and 0.22-0.29 mg/kg, respectively, much lower than those in the pot experiment. Soil HCl-extractable As in the aerobic and intermittent 


\begin{tabular}{|c|c|c|c|c|}
\hline Metal(loid) & Water treatment & Day 11 & Day 49 & Day 101 \\
\hline \multirow[t]{4}{*}{ Arsenite $(\mu \mathrm{g} / \mathrm{L})$} & Aerobic & $9.0 \pm 6.1 b$ & $0.1 \pm 0.1 c$ & $0.2 \pm 0.4 b$ \\
\hline & Intermittent-aerobic & $127 \pm 46 \mathrm{ab}$ & $49.2 \pm 15.7 b$ & $1.2 \pm 1.5 b$ \\
\hline & Intermittent & $240 \pm 90 a$ & $61.4 \pm 12.8 \mathrm{~b}$ & $108 \pm 57 a$ \\
\hline & Flooding & $298 \pm 42 a$ & $202 \pm 53 a$ & $66.6 \pm 28.9 a$ \\
\hline \multirow[t]{4}{*}{ Arsenate $(\mu \mathrm{g} / \mathrm{L})$} & Aerobic & $15.4 \pm 7.0 \mathrm{a}$ & $12.7 \pm 5.0 \mathrm{bc}$ & $21.3 \pm 4.8 \mathrm{a}$ \\
\hline & Intermittent-aerobic & $6.70 \pm 4.51 \mathrm{a}$ & $20.0 \pm 6.3 \mathrm{ab}$ & $10.4 \pm 6.8 b$ \\
\hline & Intermittent & $13.0 \pm 4.4 \mathrm{a}$ & $28.6 \pm 16.8 \mathrm{a}$ & $8.70 \pm 4.30 b c$ \\
\hline & Flooding & $4.41 \pm 1.20 \mathrm{a}$ & $3.90 \pm 4.52 c$ & $4.72 \pm 2.21 \mathrm{c}$ \\
\hline \multirow[t]{4}{*}{$\mathrm{Cd}(\mathrm{mg} / \mathrm{L})$} & Aerobic & $1.85 \pm 1.09 b$ & $1.78 \pm 0.44 \mathrm{a}$ & $1.34 \pm 0.27$ \\
\hline & Intermittent-aerobic & $1.70 \pm 0.61 b$ & $1.23 \pm 0.65 a$ & ND \\
\hline & Intermittent & $4.02 \pm 2.68 \mathrm{a}$ & $0.71 \pm 0.24 b$ & ND \\
\hline & Flooding & $1.27 \pm 2.03 b$ & $0.69 \pm 0.40 b$ & ND \\
\hline
\end{tabular}

treatments was lower than that in the conventional and flooding treatments, while soil $\mathrm{HCl}$-extractable Cd concentrations in the aerobic and intermittent treatments were slightly higher than those in the conventional and flooding treatments.

\subsection{Rice yields in the pot and field experiments}

In the pot experiment (Fig. 1a), plant growth was normal in the different water treatments except the aerobic treatment in which growth was markedly inhibited and did not reach the heading stage. The intermittent-aerobic and intermittent treatments produced similar biomass values but they were higher than the flooding treatment. In the field experiment (Fig. 1b), the conventional irrigation treatment was the most suitable irrigation regime for Brazilian upland rice and it produced the highest rice grain yield of 6.29 tons/ha. The aerobic and flooding treatments produced similar yields of about 5 tons/ha and the intermittent treatment produced the lowest average yield of 4.30 tons/ha.

\subsection{As and Cd concentrations in straw, husk and brown rice}

In general, the order of As and Cd concentrations in the different plant parts followed the order: straw > husk $>$ brown rice, except $\mathrm{Cd}$ in the pot experiment (Table 3). Water treatment

Table 2-Soil extractable As and Cd at harvest in the pot and field experiments (unit: $\mathbf{m g} / \mathrm{kg}$ ).

\begin{tabular}{llcc} 
Experiment $^{\#}$ & Water treatment & As & $\mathrm{Cd}$ \\
\hline Pot & Aerobic & $1.08 \pm 0.46 \mathrm{~b}$ & $1.04 \pm 0.33 \mathrm{a}$ \\
& Intermittent-aerobic & $0.29 \pm 0.04 \mathrm{~b}$ & $1.89 \pm 0.10 \mathrm{a}$ \\
& Intermittent & $0.58 \pm 0.47 \mathrm{~b}$ & $1.25 \pm 0.32 \mathrm{a}$ \\
Field & Flooding & $5.72 \pm 1.72 \mathrm{a}$ & $1.04 \pm 0.28 \mathrm{a}$ \\
& Aerobic & $0.03 \pm 0.01 \mathrm{~b}$ & $0.28 \pm 0.04 \mathrm{a}$ \\
& Intermittent & $0.03 \pm 0.01 \mathrm{~b}$ & $0.29 \pm 0.03 \mathrm{a}$ \\
& Conventional & $0.07 \pm 0.03 \mathrm{a}$ & $0.24 \pm 0.03 \mathrm{ab}$ \\
& Flooding & $0.06 \pm 0.00 \mathrm{ab}$ & $0.22 \pm 0.02 \mathrm{~b}$ \\
\hline
\end{tabular}

\# Soil available metal(loid)s in pot and field experiments were extracted with $1 \mathrm{~mol} / \mathrm{L} \mathrm{HAc}$ and $0.1 \mathrm{~mol} / \mathrm{L} \mathrm{HCl}$, respectively.

The same letters in the same column indicate no significant difference $(p>0.05)$. greatly affected the plant As and Cd concentrations. In the pot experiment As concentrations in straw, husk and brown rice were $4.01-89.5,2.23-6.99$, and $0.15-0.34 \mathrm{mg} / \mathrm{kg}$, respectively. As concentrations in the shoots followed the sequence: flooding $>$ intermittent $>$ intermittent-aerobic $>$ aerobic. The flooding treatment resulted in the highest As concentrations in the plants. Nevertheless, the flooding treatment also resulted in the highest concentrations of $\mathrm{Cd}$ in the straw and brown rice and the intermittent treatment produced low Cd concentrations. The husk Cd concentrations in the intermittent and

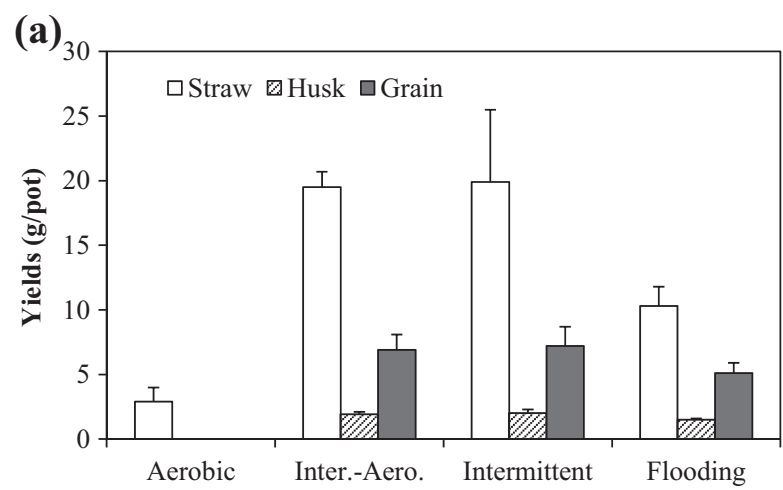

Water treatments

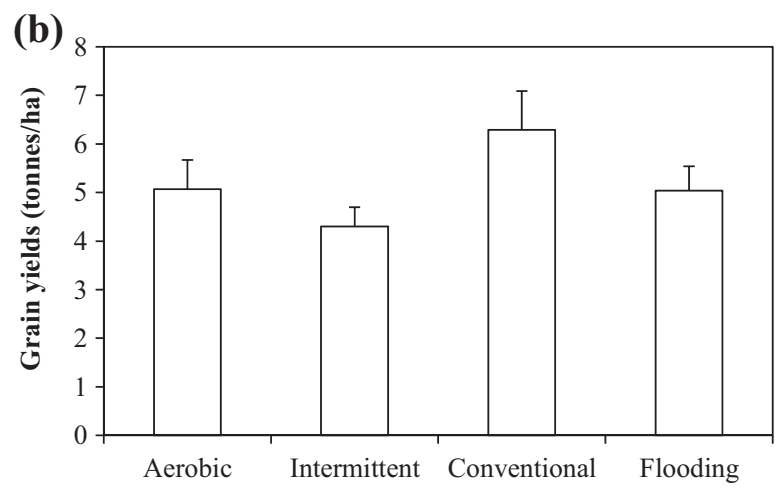

Water treatments

Fig. 1 - Rice yields under different water treatments in the pot (a) and field (b) experiments. The plants in the aerobic treatment in the pot experiment did not reach heading. 
Table 3 - Total As and Cd concentrations in rice under different water treatments in the pot and field experiments (unit: $\mathrm{mg} / \mathrm{kg}$ ).

\begin{tabular}{|c|c|c|c|c|c|c|}
\hline \multirow[t]{2}{*}{ Plant part } & \multicolumn{3}{|c|}{ Pot experiment } & \multicolumn{3}{|c|}{ Field experiment } \\
\hline & Water treatment & As & $\mathrm{Cd}$ & Water treatment & As & $\mathrm{Cd}$ \\
\hline \multirow[t]{4}{*}{ Straw } & Aerobic & $4.01 \pm 3.82 \mathrm{~d}$ & $0.20 \pm 0.07 b$ & Aerobic & $1.47 \pm 0.66 c$ & $1.76 \pm 0.28 \mathrm{a}$ \\
\hline & Intermittent-aerobic & $24.9 \pm 14.7 c$ & $0.17 \pm 0.06 b$ & Intermittent & $1.92 \pm 0.21 c$ & $1.68 \pm 0.19 a$ \\
\hline & Intermittent & $53.4 \pm 17.4 b$ & $0.15 \pm 0.02 b$ & Conventional & $3.54 \pm 0.91 b$ & $0.39 \pm 0.02 b$ \\
\hline & Flooding & $89.5 \pm 14.7 \mathrm{a}$ & $0.57 \pm 0.09 a$ & Flooding & $5.92 \pm 0.46 a$ & $0.35 \pm 0.00 \mathrm{~b}$ \\
\hline \multirow[t]{4}{*}{ Husk } & Aerobic & - & - & Aerobic & $0.58 \pm 0.12 c$ & $0.14 \pm 0.00 \mathrm{a}$ \\
\hline & Intermittent-aerobic & $2.23 \pm 0.40 \mathrm{~b}$ & $1.82 \pm 0.37 \mathrm{a}$ & Intermittent & $0.72 \pm 0.10 \mathrm{c}$ & $0.13 \pm 0.00 b$ \\
\hline & Intermittent & $3.34 \pm 0.66 b$ & $0.67 \pm 0.53 b$ & Conventional & $1.04 \pm 0.08 b$ & $0.07 \pm 0.01 c$ \\
\hline & Flooding & $6.99 \pm 1.20 \mathrm{a}$ & $0.21 \pm 0.07 b$ & Flooding & $1.61 \pm 0.20 \mathrm{a}$ & $0.08 \pm 0.02 c$ \\
\hline \multirow[t]{4}{*}{ Brown rice } & Aerobic & - & - & Aerobic & $0.14 \pm 0.02 b$ & $0.21 \pm 0.02 \mathrm{a}$ \\
\hline & Intermittent-aerobic & $0.15 \pm 0.03 c$ & $1.27 \pm 0.37 b$ & Intermittent & $0.14 \pm 0.02 \mathrm{~b}$ & $0.14 \pm 0.02 \mathrm{a}$ \\
\hline & Intermittent & $0.21 \pm 0.04 b$ & $0.22 \pm 0.06 c$ & Conventional & $0.15 \pm 0.02 b$ & $0.03 \pm 0.00 b$ \\
\hline & Flooding & $0.34 \pm 0.05 a$ & $3.25 \pm 1.01 \mathrm{a}$ & Flooding & $0.21 \pm 0.02 \mathrm{a}$ & $0.02 \pm 0.00 b$ \\
\hline
\end{tabular}

- Plants that did not reach heading stage.

The same letters in the same column indicate no significant difference $(p>0.05)$

flooding treatments were significantly lower than those in the intermittent-aerobic treatment.

In the field experiment (Table 3) as water irrigation volume increased from aerobic to flooding the straw As concentration increased from 1.47 to $5.92 \mathrm{mg} / \mathrm{kg}$ and the straw Cd concentration decreased from 1.76 to $0.35 \mathrm{mg} / \mathrm{kg}$. The brown rice As concentration in the flooding treatment $(0.21 \mathrm{mg} / \mathrm{kg})$ was significantly higher than that in the other treatments. The brown rice $\mathrm{Cd}$ concentrations in the flooding $(0.02 \mathrm{mg} / \mathrm{kg})$ and conventional $(0.03 \mathrm{mg} / \mathrm{kg})$ treatments were significantly lower than those in the aerobic $(0.21 \mathrm{mg} / \mathrm{kg})$ and intermittent $(0.14 \mathrm{mg} / \mathrm{kg})$ treatments. Husk As and Cd showed similar trends to straw and brown rice.

\subsection{Brown rice As speciation in the pot experiment}

The sum of As(III), As(V) and DMA concentrations in the brown rice in the different water treatments increased following the order: intermittent-aerobic < intermittent < flooding (Fig. 2) and this agrees well with the total As concentrations determined by mixed-acid digestion (Table 3). Water treatment greatly affected brown rice As speciation and total As

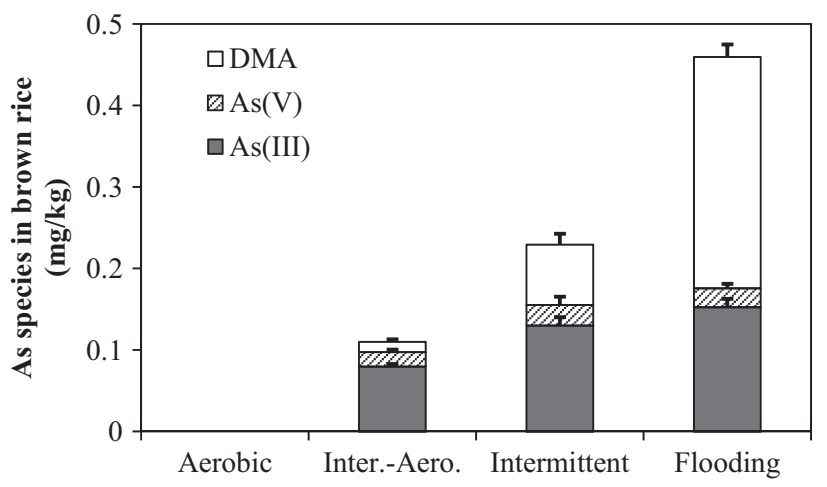

Water treatments

Fig. 2 - Arsenic speciation in rice brown rice under different water treatments in the pot experiment. The plants in the aerobic treatment did not reach heading. concentration. In the intermittent-aerobic treatment, As(III), $\mathrm{As}(\mathrm{V})$ and DMA accounted for $72.7 \%, 16.1 \%$ and $11.3 \%$ of the total As in brown rice. In the intermittent treatment, As(III), $\mathrm{As}(\mathrm{V})$ and DMA accounted for $56.7 \%, 10.9 \%$ and $32.3 \%$, respectively. However, in the flooding treatment, As(III), $\mathrm{As}(\mathrm{V})$ and DMA accounted for $33.2 \%, 5.1 \%$ and $61.7 \%$. The accumulation of DMA made a greater contribution to the increase in total As in brown rice in the intermittent and flooding treatments compared to the intermittent-aerobic treatment.

\section{Discussion}

In the present study management of water regimes markedly affected As and Cd speciation in the soil and therefore their availability to the rice plants. It is well known that plant roots take up As and Cd mainly from the soil solution and the concentration and speciation of As and Cd in the soil solution reflect their bioavailability to plants. As(III) was the predominant species of As in solution in the flooding and intermittent treatments. However, the aerobic treatment reduced by tens to hundreds of times the total As concentration in solution and this reduction was mainly in the As(III) form and also occurred during the aerobic stages of the intermittent-aerobic treatment. Therefore, compared to $\mathrm{As}(\mathrm{V})$, the changes in As(III) concentration in solution controlled the bioavailability of As to the plants as water management shifted. Similarly, $\mathrm{Xu}$ et al. (2008) reported that during the period of active rice growth the As concentration in the soil solution was 4-13 times higher under flooded than that under aerobic conditions. It was also reported that in aerobic conditions the soil redox potential increased and arsenite was oxidized to arsenate (Marin et al., 1993). Arsenate adsorbs to the surfaces of iron oxyhydroxides and this decreases the release of As into the solution phase (Xu et al., 2008). Moreover, the reductive dissolution of iron oxyhydroxides is depressed in aerobic conditions which further decreases the release of adsorbed or co-precipitated As into the solution (Takahashi et al., 2004). Therefore, under more oxidizing conditions both As(III) and $\mathrm{As}(\mathrm{V})$ are present in solution. In contrast, the water treatments 
affected Cd availability in the soil in the opposite direction to As (Tables 1 and 2). The aerobic treatment resulted in higher $\mathrm{Cd}$ concentrations in the soil solution but the flooding treatment gave lower Cd concentrations during the growing season. Arao et al. (2009) also reported that Cd concentrations in the soil solution were below the detection limit during the time of flooding but increased during aerobic conditions. These results can be explained by the combining of $\mathrm{Cd}$ with $\mathrm{S}$ to form CdS at low redox potential under flooding conditions (Bingham et al., 1976). Similar to the soil solution, the flooding treatment in the pot experiment resulted in higher concentrations of extractable As, though no significant difference was found for Cd. Nevertheless, under field conditions the water treatments showed marked effects on soil available As and Cd. The changes in As and Cd speciation in the soil influenced their bioavailability and ultimately their accumulation in the shoots (Table 3).

Consistent with As bioavailability in the soil, the flooding treatment resulted in the highest total As concentration in the plant parts among the different water treatments in both pot and field experiments. Relatively aerobic conditions (intermittent and intermittent-aerobic treatments in the pot experiment) substantially reduced As accumulation in the shoots. Similar results have been obtained in other studies (Marin et al., 1993; Li et al., 2009b; Somenahally et al., 2011). However, Cd concentrations in straw, husk and brown rice decreased markedly in higher irrigation regimes (flooding and conventional) compared to aerobic and intermittent treatments under field conditions. Thus, irrigation regime merits special attention in the mitigation of metal(loid) accumulation in rice grains when crops are grown in soils with combined pollution by As and Cd (Hu et al., 2013a, 2013b).

In the present pot experiment plant growth was greatly inhibited in the aerobic treatment and the plants failed to reach the heading stage. In field conditions the yields in the aerobic treatment were also lower than those in the other water regimes. Li et al. (2009b) also found that continuous cultivation of aerobic rice results in a substantial yield decline in greenhouse conditions. This may be due to the build-up of nematodes and soil pathogens under aerobic conditions (Ventura et al., 1981; Peng et al., 2006). Pot conditions with small soil volumes might be less buffered than field soils and the balance of underground water. On the other hand, toxicity of pollutants such as Cd might occur in aerobic conditions due to high Cd bioavailability in heavily polluted soil in pot conditions. The Brazilian upland rice cultivar usually needs less water during growth than do lowland rice varieties. Neither continuous flooding nor aerobic cultivation was the most suitable water regime. Comparatively, intermittent and intermittent-aerobic conditions in pot conditions and the conventional regime (e.g., flooding-intermittent) were suitable for acceptable yields of this cultivar. Furthermore, the responses of As and $\mathrm{Cd}$ accumulation in this upland rice cultivar to water management in this study are similar to those of lowland rice cultivars used in previous studies (Hu et al., 2013a, 2013b). Therefore, it can be speculated that the accumulation of As and $\mathrm{Cd}$ in the grains is mainly dependent on elemental availability in the soil as influenced by water management no matter what rice cultivar is grown.
Water treatment greatly affected As speciation and total As concentration in the brown rice (Fig. 2). The accumulation of DMA made a greater contribution to the increase in total As in brown rice in the intermittent and flooding treatments compared to the intermittent-aerobic treatment. Similarly, compared with flooding, aerobic treatments markedly decreased the concentration of organic As (mainly DMA) so that the percentage of inorganic As in the grain increased, although the concentrations of inorganic As remained lower than that in the flooded rice (Xu et al., 2008; Li et al., 2009b). In a field experiment in which the soil was spiked with monosodium methane-arsonate, Somenahally et al. (2011) also found that the rice grain DMA concentrations decreased by $30 \%-50 \%$ in intermittently flooded plots compared to continuously flooded plots and grain As(III) concentrations decreased by only $5 \%-30 \%$. The physiological mechanisms of As transportation and speciation transfer in plants are still poorly understood (Zhao et al., 2009). The accumulation of organic As might be by direct absorption from the rhizosphere pore water and subsequent transport to the grain (Li et al., 2009a; Somenahally et al., 2011) or it might be synthesized in the plant (Li et al., 2009b). Anaerobic conditions might favor microbial methylation and higher As(III) concentrations in the soil solution of the flooding treatment (Table 1) possibly contributed to an accelerated rate of microbial methylation of As(III) to DMA (Somenahally et al., 2011). On the other hand, methylation may be a response to As stress in plants. Enhanced methylation in rice grain in flooded conditions partly alleviates the risk of high As accumulation.

\section{Conclusions}

Intermittent and intermittent-aerobic treatments in the pot experiment and the conventional irrigation regime (e.g., flooding-intermittent) under field conditions were suitable irrigation methods for yield production by the Brazilian upland rice cultivar but continuous flooding and aerobic conditions were unsuitable. Water management affected As and Cd concentrations and speciation in the soil and their accumulation in rice shoots in opposite directions. Compared to $\mathrm{As}(\mathrm{V})$, there were more drastic changes in the As(III) concentrations in the soil solution as water management shifted, and therefore As(III) concentrations dominated the As speciation and bioavailability in soil. Consistent with As and Cd bioavailability in soil (with a few exceptions), As concentration in the rice grains increased while Cd concentrations decreased with increasing irrigation volume from aerobic to flooding. The accumulation of DMA made a greater contribution to the increase in total As in brown rice in intermittent and flooding treatments compared to intermittent-aerobic treatment. Special care is required when irrigation regime methods are employed to mitigate metal(loid) accumulation in the grain of rice grown in soils polluted with both As and Cd.

\section{Acknowledgments}

This work was supported by the National Natural Science Foundation of China (Nos. 41201300 and 41325003) and the 
High Technology Research Development Program of the People's Republic of China (No. 2012AA06A204).

\section{R E F E R E N C E S}

Arao, T., Kawasaki, A., Baba, K., Mori, S., Matsumoto, S., 2009. Effects of water management on cadmium and arsenic accumulation and dimethylarsinic acid concentrations in Japanese rice. Environ. Sci. Technol. 43 (24), 9361-9367.

Arao, T., Ishikawa, S., Murakami, M., Abe, K., Maejima, Y., Makino, T., 2010. Heavy metal contamination of agricultural soil and countermeasures in Japan. Paddy Water Environ. 8 (3), 247-257.

Bingham, F.T., Page, A.L., Mahler, R.J., Ganje, T.J., 1976. Cadmium availability to rice in sludge-amended soil under flood and non-flood culture. Soil Sci. Soc. Am. J. 40 (5), 715-719.

Chen, X.P., Zhu, Y.G., Hong, M.N., Kappler, A., Xu, Y.X., 2008. Effects of different forms of nitrogen fertilizers on arsenic uptake by rice plants. Environ. Toxicol. Chem. 27 (4), 881-887.

Cheng, J.F., Chen, S.Z., Pan, X.Y., Shen, Y.X., Chen, F.M., 2000. Effect of traits of Brazilian upland rice on its yield in different cropping systems. Acta Agric. Jiangxi 12 (3), 12-16.

Cheng, X.D., Golemovic, M., Giles, F., Zingaro, R., Gao, M.Z., Freireich, E.J., et al., 2004. Organic arsenic lipid derivatives are more potent and less toxic than inorganic arsenic trioxide in preclinical testing. Blood 104 (11), 499.

Dawe, D., 2005. Increasing water productivity in rice-based systems in Asia - past trends, current problems, and future prospects. Plant Prod. Sci. 8 (3), 221-230.

Hamdy, A., Ragab, R., Scarascia-Mugnozza, E., 2003. Coping with water scarcity: water saving and increasing water productivity. Irrig. Drain. 52 (1), 3-20.

Hu, P.J., Huang, J.X., Ouyang, Y.N., Wu, L.H., Song, J., Wang, S.F., et al., 2013a. Water management affects arsenic and cadmium accumulation in different rice cultivars. Environ. Geochem. Health 35 (6), 767-778.

Hu, P.J., Li, Z., Yuan, C., Ouyang, Y.N., Zhou, L.Q., Huang, J.X., et al., 2013b. Effect of water management on cadmium and arsenic accumulation by rice (Oryza sativa L.) with different metal accumulation capacities. J. Soils Sediments 13 (5), 916-924.

Hua, B., Yan, W.G., Wang, J.M., Deng, B.L., Yang, J., 2011. Arsenic accumulation in rice grains: effects of cultivars and water management practices. Environ. Eng. Sci. 28 (8), 591-596.

Li, R.Y., Ago, Y., Liu, W.J., Mitani, N., Feldmann, J., McGrath, S.P., et al., 2009a. The rice aquaporin Lsi1 mediates uptake of methylated arsenic species. Plant Physiol. 150 (4), 2071-2080.

Li, R.Y., Stroud, J.L., Ma, J.F., McGrath, S.P., Zhao, F.J., 2009b. Mitigation of arsenic accumulation in rice with water management and silicon fertilization. Environ. Sci. Technol. 43 (10), 3778-3783.

Li, B., Wang, X., Qi, X.L., Huang, L., Ye, Z.H., 2012. Identification of rice cultivars with low brown rice mixed cadmium and lead contents and their interactions with the micronutrients iron, zinc, nickel and manganese. J. Environ. Sci. 24 (10), 1790-1798.

Liang, F., Li, Y.L., Zhang, G.L., Tan, M.G., Lin, J., Liu, W., et al., 2010. Total and speciated arsenic levels in rice from China. Food Addit. Contam. A 27 (6), 810-816.

Liu, H.Y., Probst, A., Liao, B.H., 2005. Metal contamination of soils and crops affected by the Chenzhou lead/zinc mine spill (Hunan, China). Sci. Total Environ. 339 (1-3), 153-166.

Marin, A.R., Masscheleyn, P.H., Patrick, W.H., 1993. Soil redox-pH stability of arsenic species and its influence on arsenic uptake by rice. Plant Soil 152 (2), 245-253.

Masscheleyn, P.H., Delaune, R.D., Patrick, W.H., 1991. Effect of redox potential and $\mathrm{pH}$ on arsenic speciation and solubility in a contaminated soil. Environ. Sci. Technol. 25 (8), 1414-1419.
Meharg, A.A., Williams, P.N., Adomako, E., Lawgali, Y.Y., Deacon, C., Villada, A., et al., 2009. Geographical variation in total and inorganic arsenic content of polished (white) rice. Environ. Sci. Technol. 43 (5), 1612-1617.

Mondal, D., Polya, D.A., 2008. Rice is a major exposure route for arsenic in Chakdaha block, Nadia district, West Bengal, India: a probabilistic risk assessment. Appl. Geochem. 23 (11), 2987-2998.

Peng, S.B., Bouman, B., Visperas, R.A., Castaneda, A., Nie, L.X., Park, H.K., 2006. Comparison between aerobic and flooded rice in the tropics: agronomic performance in an eight-season experiment. Field Crop Res. 96 (2-3), 252-259.

Rahaman, S., Sinha, A.C., Mukhopadhyay, D., 2011. Effect of water regimes and organic matters on transport of arsenic in summer rice (Oryza sativa L.). J. Environ. Sci. 23 (4), 633-639.

Roberts, L.C., Hug, S.J., Dittmar, J., Voegelin, A., Saha, G.C., Ali, M.A., et al., 2007. Spatial distribution and temporal variability of arsenic in irrigated rice fields in Bangladesh. 1. Irrigation water. Environ. Sci. Technol. 41 (17), 5960-5966.

Somenahally, A.C., Hollister, E.B., Yan, W.G., Gentry, T.J., Loeppert, R.H., 2011. Water management impacts on arsenic speciation and iron-reducing bacteria in contrasting rice-rhizosphere compartments. Environ. Sci. Technol. 45 (19), 8328-8335.

Spanu, A., Daga, L., Orlandoni, A.M., Sanna, G., 2012. The role of irrigation techniques in arsenic bioaccumulation in rice (Oryza sativa L.). Environ. Sci. Technol. 46 (15), 8333-8340.

Sparks, D.L., Page, A.L., Helmke, P.A., Loeppert, R.H., Soltanpour, P.N., Tabatabai, M.A., et al., 1996. Methods of soil analysis. Part 3-Chemical Methods. Soil Sci. Soc. Am. Inc., Madison, USA.

Takahashi, Y., Minamikawa, R., Hattori, K.H., Kurishima, K., Kihou, N., Yuita, K., 2004. Arsenic behavior in paddy fields during the cycle of flooded and non-flooded periods. Environ. Sci. Technol. 38 (4), 1038-1044.

Tsukahara, T., Ezaki, T., Moriguchi, J., Furuki, K., Shimbo, S., Matsuda-Inoguchi, N., et al., 2003. Rice as the most influential source of cadmium intake among general Japanese population. Sci. Total Environ. 305 (1-3), 41-51.

Ventura, W., Watanabe, I., Castillo, M.B., Delacruz, A., 1981. Involvement of nematodes in the soil sickness of a dryland rice-based cropping system. Soil Sci. Plant Nutr. 27 (3), 305-315.

Williams, P.N., Price, A.H., Raab, A., Hossain, S.A., Feldmann, J., Meharg, A.A., 2005. Variation in arsenic speciation and concentration in paddy rice related to dietary exposure. Environ. Sci. Technol. 39 (15), 5531-5540.

Williams, P.N., Lei, M., Sun, G.X., Huang, Q., Lu, Y., Deacon, C., et al., 2009. Occurrence and partitioning of cadmium, arsenic and lead in mine impacted paddy rice: Hunan, China. Environ. Sci. Technol. 43 (3), 637-642.

Xu, X.Y., McGrath, S.P., Meharg, A.A., Zhao, F.J., 2008. Growing rice aerobically markedly decreases arsenic accumulation. Environ. Sci. Technol. 42 (15), 5574-5579.

Ye, X.X., Ma, Y.B., Sun, B., 2012. Influence of soil type and genotype on Cd bioavailability and uptake by rice and implications for food safety. J. Environ. Sci. 24 (9), 1647-1654.

Zavala, Y.J., Gerads, R., Gurleyuk, H., Duxbury, J.M., 2008. Arsenic in rice: II. Arsenic speciation in USA grain and implications for human health. Environ. Sci. Technol. 42 (10), 3861-3866.

Zhang, J., Duan, G.L., 2008. Genotypic difference in arsenic and cadmium accumulation by rice seedlings grown in hydroponics. J. Plant Nutr. 31 (12), 2168-2182.

Zhao, F.J., Ma, J.F., Meharg, A.A., McGrath, S.P., 2009. Arsenic uptake and metabolism in plants. New Phytol. 181 (4), 777-794. 